\title{
Correction to: HTA and MCDA solely or combined? The case of priority-setting in Colombia
}

Héctor E. Castro ${ }^{1}$, Ornella Moreno-Mattar ${ }^{2^{*}}$ and Juan C. Rivillas ${ }^{2}$

\section{Correction to: Cost Eff Resour Alloc (2018) 16:47} https://doi.org/10.1186/s12962-018-0127-6

Following publication of this supplement article [1], the authors reported an error in the citation provided in the caption of Fig. 1.

For the correct citation, please see the corrected version of Fig. 1 in this article.

The authors apologize for any inconvenience caused.

\section{Author details}

${ }^{1}$ Pharmaceutical Economics \& Financing EN Management Sciences for Health, Manager Sciences for Health, Arlington, USA. ${ }^{2}$ Ministry of Health and Social Protection, Bogotá, Colombia.

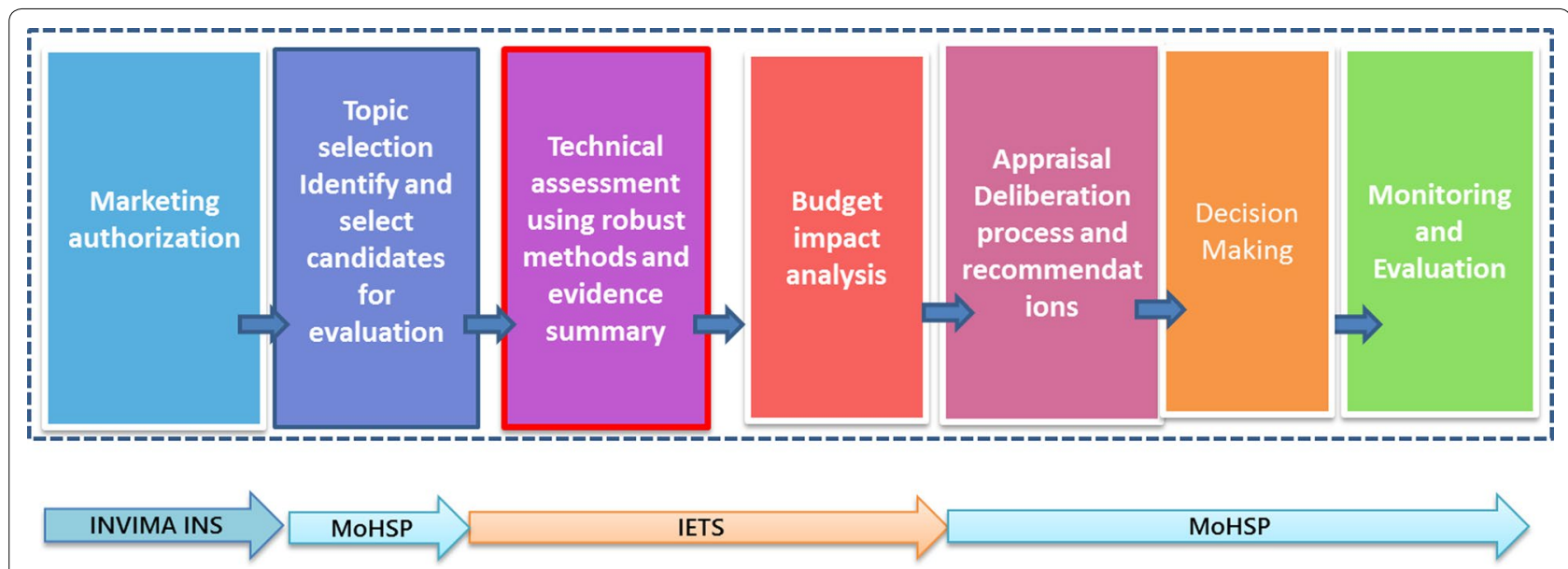

Fig. 1 Decision-making in health and healthcare in Colombia (Source: Adapted by the authors from Red CRITERIA, BID 2015 https://publicatio ns.iadb.org/publications/spanish/document/Serie-de-notas-técnicas-sobre-procesos-de-priorización-en-salud-Nota-2-Un-enfoque-sistémico.pdf)

The original article can be found online at https://doi.org/10.1186/s1296

2-018-0127-6.

*Correspondence: ornellamorenomattar@gmail.com

${ }^{2}$ Ministry of Health and Social Protection, Bogotá, Colombia

Full list of author information is available at the end of the article

\section{$\triangle B M C$} adaptation, distribution and reproduction in any medium or format, as long as you give appropriate credit to the original author(s) and the source, provide a link to the Creative Commons licence, and indicate if changes were made. The images or other third party material in this article are included in the article's Creative Commons licence, unless indicated otherwise in a credit line to the material. If material is not included in the article's Creative Commons licence and your intended use is not permitted by statutory regulation or exceeds the permitted use, you will need to obtain permission directly from the copyright holder. To view a copy of this licence, visit http://creativeco mmons.org/licenses/by/4.0/. The Creative Commons Public Domain Dedication waiver (http://creativecommons.org/publicdomain/ zero/1.0/) applies to the data made available in this article, unless otherwise stated in a credit line to the data. 
Published online: 07 October 2020

\section{References}

1. Castro HE, Moreno-Mattar O, Rivillas JC. HTA and MCDA solely or combined? The case of priority-setting in Colombia. Cost Eff Resour Alloc. 2018;16(Suppl 1):47. https://doi.org/10.1186/s12962-018-0127-6.

\section{Publisher's Note}

Springer Nature remains neutral with regard to jurisdictional claims in published maps and institutional affiliations.
Ready to submit your research? Choose BMC and benefit from:

- fast, convenient online submission

- thorough peer review by experienced researchers in your field

- rapid publication on acceptance

- support for research data, including large and complex data types

- gold Open Access which fosters wider collaboration and increased citations

- maximum visibility for your research: over 100M website views per year

At BMC, research is always in progress.

Learn more biomedcentral.com/submissions 